Section Editor: IGOR I. KAVASS

\title{
BRITISH AND IRISH ASSOCIATION OF LAW LIBRARIANS
}

The next annual conference of the British and Irish Association of Law Librarians will take place at the University of Warwick in Coventry, September 11-14, 1981.

\section{NEW PUBLICATION OF AUSTRALIAN STATUTES ANNOUNCED}

The Attorney-General of Australia has announced plans to publish updated copies of Commonwealth and federal territory legislation in the form of pamphlets to be kept in binders. Existing pamphlets will be replaced whenever significant revision occurs. Lesser changes will be printed in pages to be placed in the binders following the respective pamphlets. This new publication policy is expected to provide a continuously current and complete set of Commonwealth Acts and territorial laws.

The project will reportedly begin with a reprint of ordinances and regulation of the Australian Capital Territory. Publication of updated reprints of Commonwealth Acts and Commonwealth Statutory Rules will follow. The bound volumes of statutes issued annually will continue to be published.

Howard A. Hood

Vanderbilt University

\section{REPRINT SOURCES}

Due to the unavailability of so many items from antiquarian and outof-print dealers, libraries must turn to reprints for crucial works (and, indeed, primary sources) of historical significance. Verlag Detlev Auvermann KG and Topos Verlag have produced impressive annotated catalogs of wide scope on books of such antiquarian character. The quality of the reprints themselves is noteworthy. Some examples of the titles reprinted include the Projet of the Code Civil by Cambaceres, the Montalvo edition of Las Siete Partidas printed in 1501 by Lucantonio de Giunta in Venice (although we have not received this as yet), The Acts and Constitutions of the Realm of Scotland (Edinburgh, 1566) and Austin's Lectures on Jurisprudence. 